\title{
Article
}

\section{The great European Cup-Tie final, East Surreys v Bavarians, kick off at zero, NO REFEREE!}

\author{
Adams, lain Christopher \\ Available at http://clok.uclan.ac.uk/33970/ \\ Adams, Iain Christopher (2020) The great European Cup-Tie final, East Surreys \\ v Bavarians, kick off at zero, NO REFEREE! Soccer \& Society . ISSN 1466-0970
}

It is advisable to refer to the publisher's version if you intend to cite from the work. http://dx.doi.org/10.1080/14660970.2020.1791829

For more information about UCLan's research in this area go to http://www.uclan.ac.uk/researchgroups/ and search for < name of research Group>.

For information about Research generally at UCLan please go to http://www.uclan.ac.uk/research/

All outputs in CLoK are protected by Intellectual Property Rights law, including Copyright law. Copyright, IPR and Moral Rights for the works on this site are retained by the individual authors and/or other copyright owners. Terms and conditions for use of this material are defined in the policies page.

\section{CLoK}

Central Lancashire online Knowledge www.clok.uclan.ac.uk

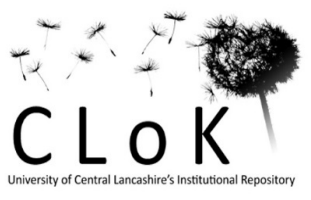




\title{
The Great European Cup-Tie Final, East Surreys v Bavarians, Kick off at Zero, NO REFEREE!
}

\author{
Iain Adams
}

Independent Researcher

Correspondence to: Iain Adams, 2 Lentworth Hall, Abbeystead, Lancashire, LA2 9BE, UK.

Email: icadams152@gmail.com

Iain Adams was chief pilot of Vectair Aviation before retiring and taking up a position at the University of Central Lancashire where he carried out research under the auspices of the International Football Institute before again retiring. He was made an Honorary Fellow of the British Society of Sports History in 2019 and is currently researching sport aviation in the Weimar Republic. 


\section{The Great European Cup-Tie Final, East Surreys v Bavarians, Kick off at Zero, NO REFEREE!}

The image of British troops advancing into battle kicking a football is part of Britain's First World War collective memory. However, research suggests that this happened only twice, with the better-known event being on the opening day of the Battle of the Somme when 'B' Company of the 8 Battalion of the East Surrey Regiment kicked two footballs ahead of them. The East Surreys were one of the few battalions to reach their objective. However on this bloodiest day in the history of the British Army, the football charge is but a footnote to military historians despite becoming a national 'micro-level' myth. This paper, researched in an antiquarian spirit, is concerned with the recovery of the empirical detail of the event motivated by a desire to discover the objective reality of the collective memory and explore the underlying rationale of this 'football charge'.

Keywords: First World War; football charge; East Surrey; The Somme; masculinity; displacement

\section{Introduction}

In 2011 Robert Hands opined that the most famous symbiosis between war and sport occurred in the Great War with legendary football matches between British and German troops at Christmas 1914 and the developing tradition of British troops 'kicking a football out of the trenches before going over the top'. Vamplew pointed out that these events created sporting images that are part of Britain's collective memory and termed them 'micro-myths' as neither of these images is totally false. ${ }^{1}$

Research has established that a formal or semi-formal football match between British and German troops did not occur at Christmas 1914 although the combatants discussed the possibility at a local level. However, informal kickabouts probably took place at several locations. ${ }^{2}$ The collective memory of British football charges is based upon two events, the first at Loos on 25 September 1915 and the second on the first day of the Somme offensive, 1 July 1916. There are uncorroborated and isolated reports of 
other instances of footballs being dribbled forward but these have not been corroborated. Holmes urged caution in the use of memories of veterans recalled decades later as recollections became more comprehensive through reflection and refraction even when becoming more unreliable through time, excitement, confusion and subsequent experiences. Stories and events related to soldiers took on firsthand experience as individuals 'reflect the past through the prism of the present.' ${ }^{3}$

This article seeks to answer the question of what actually happened, and why, in the second, and most well-known of the football charges, that undertaken by ' $\mathrm{B}$ ' Company of the 8 Battalion of the East Surrey Regiment (8/East Surrey) during the opening moments of the Battle of the Somme. A systematic review of material from a variety of sources, stressing a posterior evidence from individuals present on the day, is utilized. Shortly after the battle, the poet John Masefield visited the battlefield and reflected that 'What it was like on the day of battle cannot be imagined by those who were not there. $^{4}$

\section{Prelude to the Somme}

The Western Front had stabilized into a stalemate by late November 1914 with parallel trench lines stretched over 440 miles from the Belgian Coast to Switzerland. The Germans occupied 'a large and economically invaluable tranche of France and Belgium' and had extensively fortified their front; 'they were there for the duration'.5 The Allies had to go on the offensive to evict the occupiers.

The French and British began planning a major offensive in December 1915 to end the deadlock. The allies would attack on a 60 mile front in the Somme department, the British to the north and the French to the south. The offensive objectives were to draw German troops and matériel away from the Verdun front and to inflict heavy losses on the German army. General Douglas Haig endorsed the plan when he became 
Commander-in-Chief of the British Expeditionary Force (BEF) on the 19 December 1915 despite the planned battle ground not meeting his approval. Nevertheless, he recognized the need to maintain allied concord and the objectives aligned with his attritional strategy. ${ }^{6}$ However, he requested delaying the attack until late 1916 in order to train his new volunteer army as they were to face formidable obstacles. The Germans had constructed a fully-realised defensive system at the Somme with a front line comprised of three trenches 200 metres apart fronted by two barbed wire systems each over 20 metres thick and up to 3 metres high. Fortified villages and trench redoubts were incorporated into the front line along with large dug-outs over 18 metres deep. A second defensive line was in place 1800 to 4500 metres behind the front line and a third line was under construction a further 3000 metres back.

A surprise onslaught by the Germans at Verdun in February 1916 began a sustained trial for the French and their reserves were committed to battle. As a consequence the primary aim of the Somme became to relieve 'the severely reduced and battered French' by drawing German forces away from Verdun. ${ }^{7}$ French desperation forced Haig to act before he was ready but he developed a further objective for the attack which he believed would place the British Army in a favourable position for a final victory in 1917. This required the capture of a ten mile strip of the Pozières Ridge from Montauban-de-Picardie to the River Ancre and one of the assigned units was the 8/East Surreys. The Battle of the Somme began on 1 July 1916 and ended on 18 November 1916 and it remains Britain's most costly and controversial battle. ${ }^{8}$

\section{The 8/East Surreys}

The battalion was raised in September 1914 as part of 18 Division's 55 Brigade, an element of Kitchener's second New Army Group. Their early days were chaotic in 'a desolate colony' of too few tents at Purfleet on the Thames marshes; 'there were not 
enough blankets to go round; their food was coarse; there were no recreation huts, no dining halls, no canteens' and no uniforms or weapons, not even wooden dummy rifles for basic drill. ${ }^{9}$ The adjutant, Captain Irwin, recalled the first few weeks were a 'hard and miserable life' and his initial aims, alongside basic military training, were to keep the men fed and to improve their fitness. To this latter end, he acquired footballs which also kept the men amused after the day's training was complete. ${ }^{10}$ This had the added benefit of increasing and maintaining morale as many of the 8/East Surreys were keen footballers. Teddington Town FC's president noted that his first and second teams had enlisted en masse to the East Surreys whose recruiting office used the slogan 'Footballers wanted for the big game! Apply within'. Also, the regiment had recruited successfully at the football grounds of the smaller London clubs such as Brentford and Queens Park Rangers, a recruitment office had even been established at the Rangers' Park Royal ground. ${ }^{11}$

The Brigade moved to Colchester to join the division in April 1915 after completing basic and brigade training. The commander, Major-General Ivor Maxse, established football and rugby competitions immediately to help develop esprit de corps and fitness during divisional training. In late July 1915 the division embarked for France to begin trench warfare preparation and here they found a developed football scene. ${ }^{12}$ Waquet noted that when the BEF had initially arrived in August 1914 'the soldiers of His Majesty King George V landed in France, rifle and ball in hand' ${ }^{13}$ Most BEF battalions managed to include football in their daily lives when out of the front line despite the fluid and vicious fighting of late summer and autumn 1914; for example Captain James Jack noted on the 4 October that the daily after-dinner routine of his Cameronians battalion included 'ordinary duties, working parties and games - chiefly football' ${ }^{14}$ The stabilization of the front in November 1914 allowed more formal and 
larger football competitions to be organized such as that of the 1 Cavalry Brigade in January 1915. Brigadier-General Briggs provided a cup and 45 teams from his brigade competed. The Graphic newspaper on 5 June 1915 devoted a double page spread showing 'a typical scene' of men resting by playing football behind the lines. In July 1915 Haig complained that the men were falling asleep on night sentry duty because they were playing football in their rest periods. ${ }^{15}$

The 8/East Surreys began front line duties in August 1915 but were resting in billets for their first anniversary, 10 September. ${ }^{16}$ Football remained an intrinsic part of battalion life and, as Wilfred 'Billie' Nevill, a battalion officer noted of the anniversary:

The afternoon was devoted to football but,... only those with the energy to carry rifle and equipment turned up to encourage the 22 drops of sweat who were racing about in 106 degrees Fahr. and long trousers. At half-time a sand-bag full of apples masqueraded as a plate of lemons. ${ }^{17}$

The battalion remained in billets until the evening of the 26 September and Nevill remarked that during this period there was 'football as often as we wanted it ... being in billets is really ripping fun'. ${ }^{18}$

In January 1916 Maxse ordered that football was to be considered part of training and each platoon must have a team and headquarter companies two teams. ${ }^{19}$ The men were to play 'football in the afternoons' because after front line duty 'all ranks will be more-or-less rusty and slow in movement' ${ }^{20}$ In April, detailed plans for the Somme assault were announced and training increased but sport was still utilised to keep the men fit and in high spirits; football matches and tournaments were regularly organised in the run up to the Somme assault. ${ }^{21}$ On 5 June the battalion began training against trenches laid out to represent the German positions they were to attack. The 
work was intense but Irwin remembered that he gave them 'some fun in the afternoon'. 22

Billie Nevill

Billie Nevill was 21 when the 8/East Surreys arrived in France. He was from a middle class family and had had an outstanding sporting career at Dover College where he played on the school cricket and hockey teams for four of his five years. In his final year he was Head Boy and captain of both first teams. When the war began he had just completed his first year at Jesus College, Cambridge reading Classics and playing hockey. He volunteered and underwent officer training before joining the East Yorkshire Regiment but, as it had a full complement of officers, he was seconded to the East Surreys which he joined after Christmas $1914 .{ }^{23}$ On the battalion's departure to France he was second in command of 'C' Company and on the 13 September 1915 he was notified that he had been promoted from Temporary Lieutenant to Temporary Captain. In March 1916 Nevill was given command of 'B' Company and he reflected: You know sometimes I sit down \& laugh to myself when I think what I was before this bally War. Now I've got 200 odd men, solely under me, to feed, pay, clothe, house, advise on every conceivable subject, lecture, teach, \& order about in emergencies, organise, act as judge to, in fact every blooming thing, \& the funniest part of it all is that it doesn't worry me a bit or awe me, though the thought of it in England used to frighten me a bit ... I feel absolutely confident in the men themselves \& that's why I feel confident in myself. ${ }^{24}$

Following the German offensive at Verdun in February 1916, the soldiers of the 18 Division knew that a relief assault was inevitable to take pressure off the French and the 
discussion in the officers' mess was often centred on the comportment of the men in their forthcoming first big battle. ${ }^{25}$

As a new company commander, Nevill studied his men's mental and temperamental characteristics and from early 1916 a 'sprightly Trench Gazette ... entirely written by Nevill ... somewhat bawdy, full of local "jokes" was started which was passed around in the trenches and the men loved it. ${ }^{26}$ In May he returned home for a brief period on leave and bought three footballs for his company on a shopping trip with his brother Howard. However according to his other brother, the Rev. T.S. Nevill, he only took two of the balls back for his men. It is not known whether these balls were intended purely for his company's recreation or if he was already planning a football charge. ${ }^{27}$ It is likely that Nevill knew about the London Irish Rifles 'football charge' at Loos in 1915 when they had achieved all of their objectives, one of the few successes at Loos. As preparations for the Somme attack developed, Nevill asked Irwin, now a major and the battalion commanding officer, for permission to use footballs. Irwin recalled:

A few days before the Battle of the Somme he (Nevill) had come to me with a suggestion that as he and his men were all equally ignorant of what their conduct would be when they got into action; he thought it might be helpful as he had 400 yards to go and knew that it would be covered by machine-gun fire, it would be helpful if he could furnish each platoon with a football and allow them to kick it forward and follow it. That was the beginning of the idea and I sanctioned that on condition that he and his officers really kept command of their unit and didn't allow it to develop into a rush after the ball, just if a man came across the football he could kick it forward but he mustn't chase after it. ${ }^{28}$ 
In a trench publication, the Billon Valley Baloonist (sic) Windy Words, circulated during the battalion's brief sojourn in the Billon Valley between 28 and 30 June, a note read 'INTERNATIONAL FINAL. ENGLAND V GERMANY. KICK OFF. -ZERO. NO REFEREE'. ${ }^{29}$

On the afternoon of Friday, 30 June, the 8/East Surreys moved to their start positions (Figure 1) on Le Grands Sarts just north-east of the village of Carnoy and

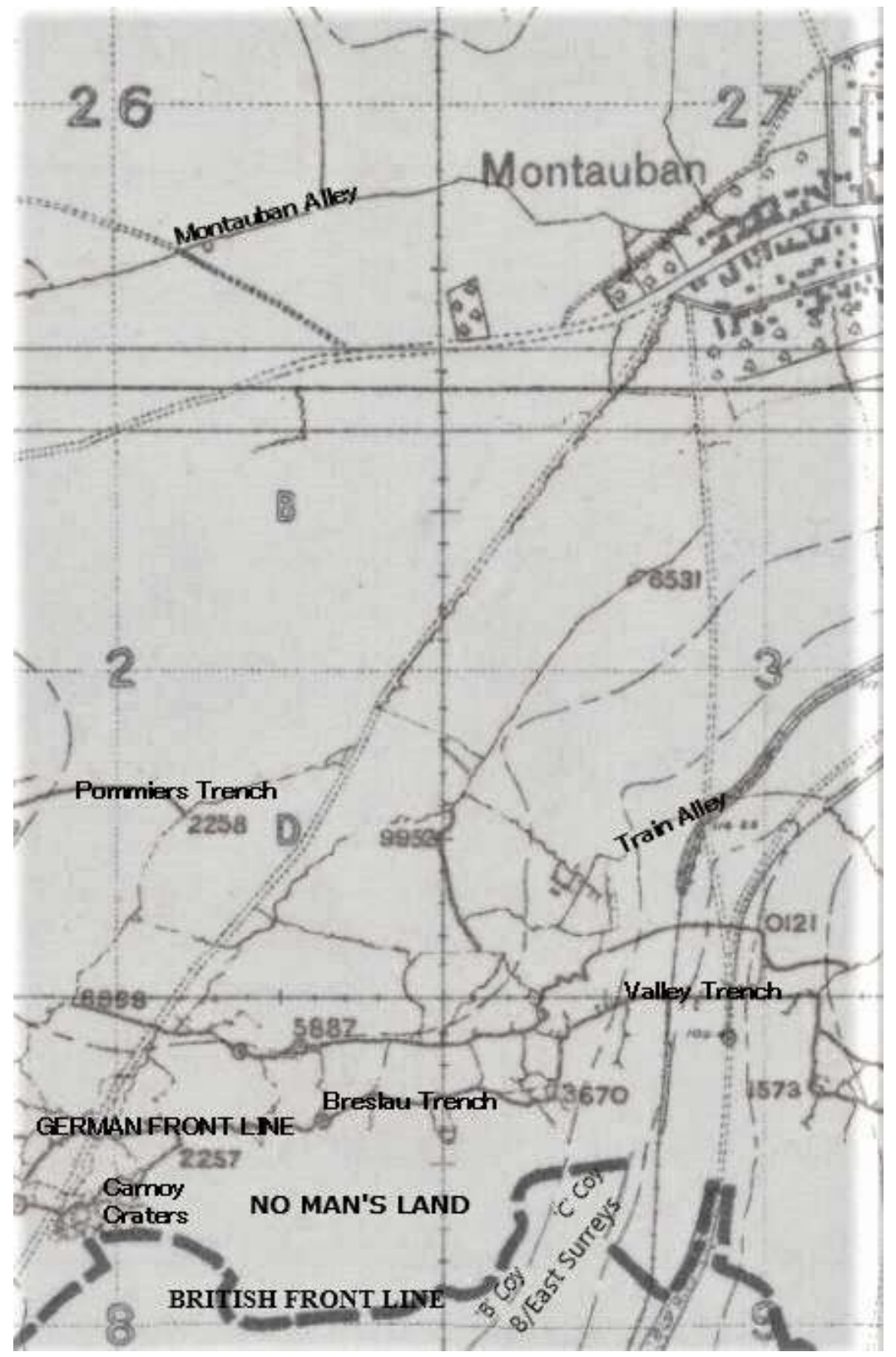

Figure 1. 8/East Surreys start position and objectives. Reproduced with the permission of the National Library of Scotland 
Nevill offered a prize to whoever kicked a ball into the German front line first. On one ball somebody wrote 'The Great European Cup - the Final - East Surreys v. Bavarians, Kick-off at Zero' and on the other was written 'NO REFEREE' indicating that rough stuff was appropriate. ${ }^{30}$ The battalion was towards the southern part of the British attack occupying 300 metres of front line trenches on a slightly raised promontory with a 'reentrant' in the left of their section forming a distinct kink in the front line. The attack was to be led by two platoons of ' $\mathrm{C}$ ' Company on the right and two platoons of ' $\mathrm{B}$ ' Company on the left in the re-entrant. The other two platoons of each company were positioned in the second Assembly trench to make up the third and fourth waves of the attack. 'D' Company was in support and 'A' Company was in battalion reserve. ${ }^{31}$

\section{The Football Charge}

The battalion objectives were to capture the Breslau Trench which was part of the German front line about 400 metres away before proceeding up the ridge to take 300 metres of the Montauban Alley communication trench, north of the Montauban-Mametz $\operatorname{road}\left(\right.$ Figure 1). ${ }^{32}$

An eight day artillery bombardment preceded the infantry assault at 07.30 on 1 July 1916. Before 06.00 mist restricted visibility to a few metres in the 8/East Surreys area, but by 06.30 the mist cleared revealing a blue sky, hot sun and unrestricted visibility. German sentries could see that the barbed wire in front of the British trenches had been removed overnight to allow the troops access to No Man's Land. Realizing an attack was imminent, an immediate heavy German artillery barrage was requested and 'B' Company suffered several casualties and their trenches were flattened in places as they prepared to go over the top; the bombardment continued for several hours. At Zero Hour officers blew their whistles and the troops climbed out of their trenches and formed up before proceeding across No Man's Land. The advance was to be made at 
walking pace in long lines with the men 2 to 5 metres apart and the waves 50 to 100 metres apart. Due to ' $\mathrm{B}$ ' Company manning the re-entrant they had to leave their trenches early and rotate into line with the ' $\mathrm{C}$ ' Company soldiers as they emerged from their trenches at 07.30. According to the Battalion War Diary:

At 7.27 "B" Company moved out to their wire, Captain Nevill strolling quietly ahead of them, giving an occasional order to keep the dressing square on to the line of advance. This company took four footballs out with them which they were seen to dribble forward into the smoke of our intense bombardment on the Hun front line. ${ }^{33}$

Private Price of the 8/Royal Sussex Regiment stated:

As the gun-fire died away I saw an infantryman climb onto the parapet into No Man's Land, beckoning others to follow. As he did so he kicked off a football; a good kick, the ball rose and travelled well towards the German line. That seemed to be the signal to advance. ${ }^{34}$

There were few casualties in the first part of the advance but when the artillery barrage lifted from the German front line, a very heavy rifle and machine-gun fire started from their left and from the front. The East Surreys sustained casualties from enfiladed fire from machine guns in the Carnoy craters (Figure 1). ${ }^{35}$ However, other reports show this enfilading fire began at 07.27 prompted by the appearance of ' $\mathrm{B}$ ' Company climbing from their trenches; 'they were met by very heavy machine-gun fire from the craters on their left but made steady progress.' By 07.50 the Adjutant reported hand to hand fighting in the German trenches and news was received that Captains Flatau, Pearce, and Nevill, Lieutenants Musgrove and Soames, and 2 Lieutenants Kelly and Evans had been killed. ${ }^{36}$ 
The battalion continued to suffer heavy casualties and Major Irwin sent for reinforcements at 08.25. By 09.21 the 8/East Surreys were fighting in the Pommiere Line and moving into Train Alley, however they had suffered 'extremely heavy casualties' and with the attack losing momentum and with some lack of direction evident, Major Irwin went forward at 09.44 and requested further reinforcements to continue the attack. At 10.45 the battalion was observed at Breslau Alley, about 3 hours behind schedule. At 12.10, with less than 200 men remaining, the East Surreys moved forward from Breslau Alley reaching the road west of Montauban at 12.22 and by 12.35 their objective, Montauban Alley, was secure. ${ }^{37}$ The War Diary further noted:

Later L/C Brame turned up with a bottle of champagne to be drunk in MONTAUBAN “ON DER TAG” This bottle was sent round from Officer to Officer, those who shared in it being Major Irwin, Captain Gimson, Captain Bowen, 2/Lieut. Derrick, 2/Lieut. Janion, Lieut Thorley, 2/Lieut

Wightman, 2/Lieut Alcock and Captain Clare, in fact all of the East Surrey

Officers engaged in the attack who had not been killed or wounded.

The battalion held the position until being relieved at 04.30. Nevill was buried with the other battalion officers at 14.00 on the 3 July in Carnoy Valley. ${ }^{38}$

\section{After the Battle}

The 1 July 1916 is regarded as the blackest day in British military history; by nightfall over 19,000 British soldiers had been killed, some 2,000 were missing and over 35,000 wounded out of the 120,000 who had advanced. ${ }^{39}$ The 8/East Surreys lost 148 men killed, 274 wounded and 20 missing, most casualties occurring in the first ten minutes. They won 21 gallantry medals but most acts of bravery go unrewarded by decoration. Maxse told Irwin that he had the greatest pride and admiration for their work and that the battalion had made an immortal name for itself. ${ }^{40}$ 
There had been little press coverage of the football charge of the London Irish a year earlier but, following the alarming losses at the Somme, Nevill's enterprise helped divert the nation's attention. It captured the public imagination with a story of heroism and courage that supported the concept of an invincible British sporting spirit. The Illustrated London News (Figure 2) published a double page illustration of the East Surreys attack, 'The Surreys Play the Game', on the 29 July 1916. The script noted 'The Captain of one of the companies had provided four footballs, one for each platoon, urging them to keep up a dribbling competition all the way over the mile and a quarter of ground they had to cover'.

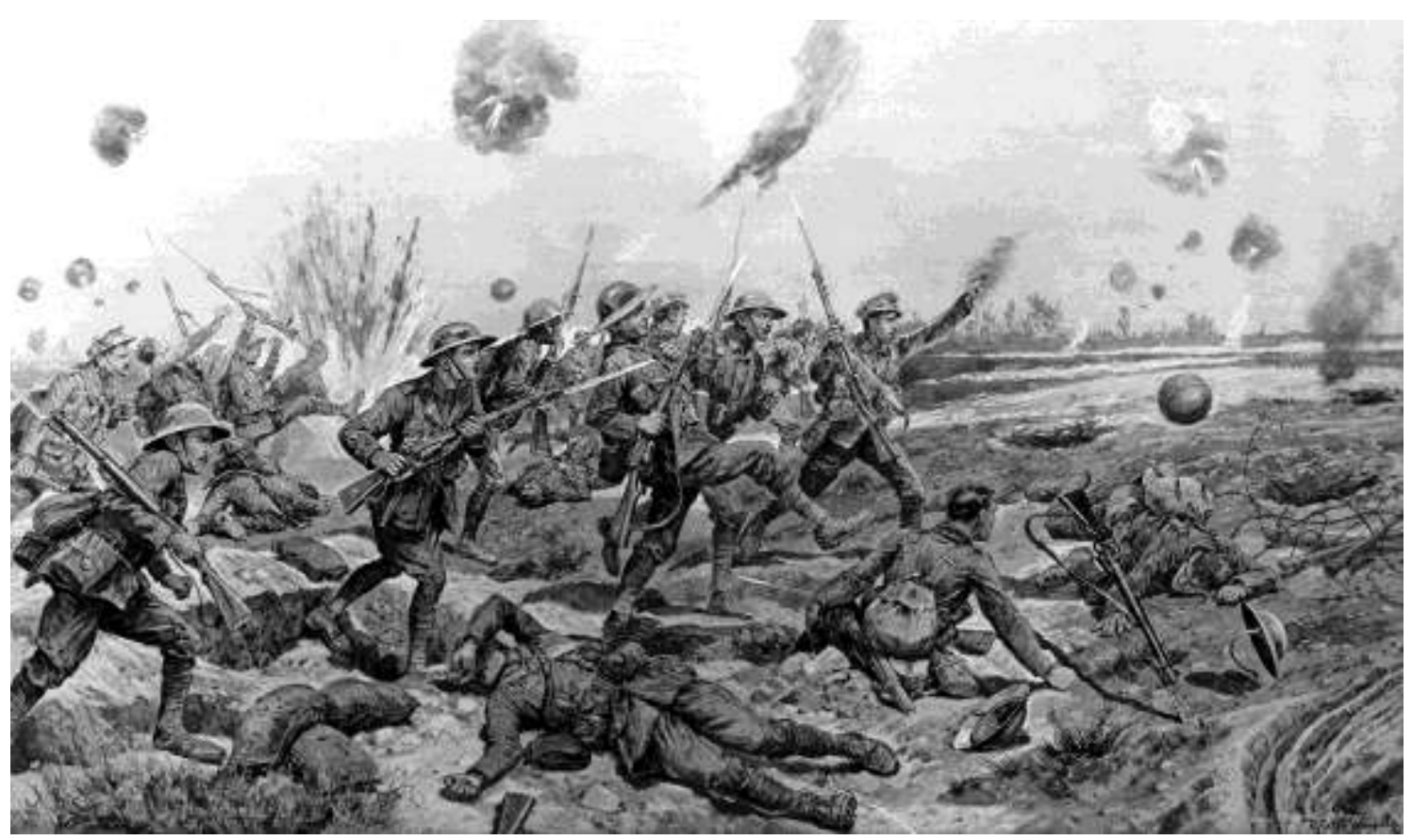

Figure 2. 'The Surreys Play the Game' Illustrated London News, 29 July, 1916, 134-135. Source: Mary Evans Picture Library

Woodville's realistic graphic style catered to jingoistic appetites and he always provided good propaganda representing British actions in the best possible light showing individual acts of heroism with a moral and universal meaning. The representation of the football charge embodies the indomitable spirit and triumph of British character over adversity whilst showing the German soldier the impossibility of 
the task of overcoming the spirit and will of Tommy Atkins. The illustration reinforced the general message of the press that the spirit of Britain's national games remained in her soldiers in the great game of war; each Tommy had conducted himself with fortitude in battle and played his part valuably and honourably, demonstrating 'his natural superiority over his German counterpart' by his fondness for playing. The promotion of the football charge could help maintain support for the war on the home front as the public could see that the fighting was being done by ordinary men from Britain's working communities. ${ }^{41}$ The Somme was the first use of Kitchener's second New Army Group, an organisation representative of a united nation; it had to be seen as courageous and victorious. The losses resulted in nearly everybody in Britain being touched by the war and the sacrifice could not be portrayed as being in vain in order to maintain the war effort on both fronts; the sacrifice had to be justified. ${ }^{42}$

Nearly a hundred years later an illustration by Percy E. Syer, an 8/East Surrey soldier at the Somme, was discovered in the archives of the regiment and published (Figure 3). The work is less triumphant than Woodville's having an 'ethereal and poignant' atmosphere with a dead German and mortally wounded British soldiers 'setting up a dialogue of loss for both sides'. The upright posture of the men shows progress is being made but all of the men look steadfastly ahead, locked into their own world and determined to see the horror through. The football appears incidental, not belonging to the soldiers. The London Irish football charge had been the men's idea carried out against the orders of their officers whilst the 8/East Surrey football charge was an officer's idea. Syer's image seems to be illustrating the developed resilience of the combat soldier who is all too aware of his frailty rather than the heroic deathdefying charge of the newspapers. ${ }^{43}$ 


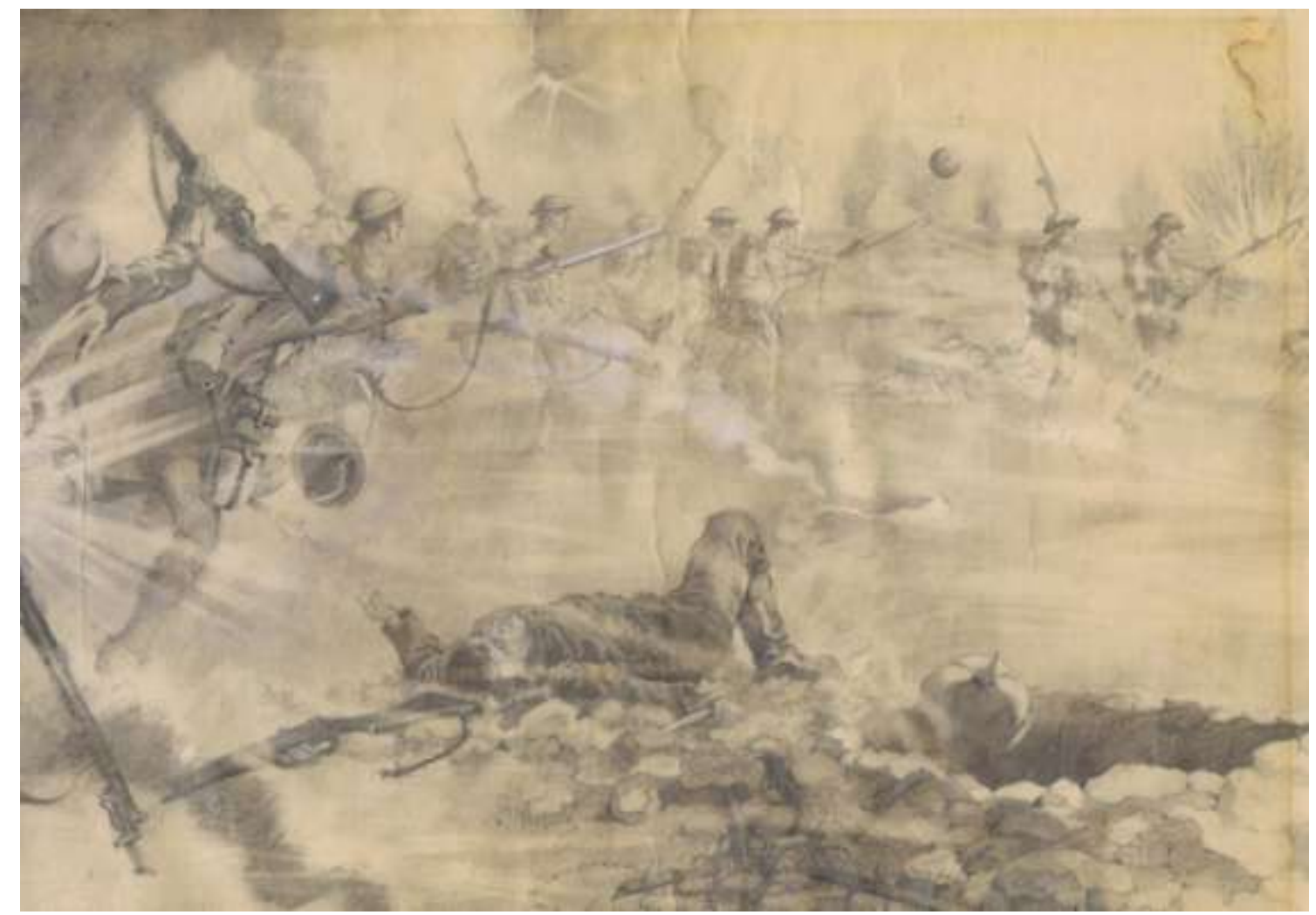

Figure 3. 'The East Surreys’ Attack’ by Percy Syer. Source: Surrey Infantry Museum.

The two footballs were recovered from the German wire and returned to the regimental depot at Kingston-upon-Thames. The balls were used to raise funds for regimental charities often accompanied by survivors of the charge during the remainder of the war. ${ }^{44}$ They eventually became prize museum exhibits, one at Dover Castle and the other at the Surrey Infantry Museum at Clandon Park House, Surrey. Sadly a fire at Clandon Park on the 29 April 2015 destroyed their ball alongside most of the regiment's memorabilia, including Syer's sketch.

\section{Discussion}

Although the broad details of the East Surrey attack on the first day of the Somme are described, some details remain contentious. These include why footballs were used and when it was decided to use them, how many footballs were involved, who kicked off, and where was Nevill killed. 
The 8/East Surreys football charge has been interpreted in different ways. In the immediate aftermath the British press saw the act as demonstrating the indomitable British spirit, the 'British sportsman-soldier leading the fight against the Hun' whereas some German newspapers reprinted Woodville's image to demonstrate the stupidity of the British. Later some commentators thought it a risible gesture illustrating an early view that war was simply another game or it was the idea of a man 'obsessed with sport', 'an act of stupid bravado'. ${ }^{45}$ However evidence from his fellow officers and his Commanding Officer, Major Irwin, shows that Nevill decided to use footballs as a distraction from the terrors that the men experienced as they faced their baptism of 'going over the top', defying the horror of the immediate future. The decision was made after reflection rather than as an acte gratuity. Autobiographies and letters reveal that amongst the fears of many of the men waiting for an assault to begin was that they would let their comrades down. By this stage of the war, loyalty and duty to the Crown or nation as a combat motivation was being replaced by an intense comradeship, a responsibility for and dependence on the members of the section or platoon. The football may have replaced the regimental flag as the talisman representing esprit de platoon. $^{46}$

It is not known when Nevill decided to use footballs in the attack. The officers discussed how they, and their men, would behave in their first battle and these discussions would have intensified as the 8/East Surreys rehearsed the attack against the replica German defences. It may have been a realization of the formidable nature of these defences that made Nevill think about a distraction and to consider footballs as 'a highly unusual, almost bizarre, accompaniment to an attack' ${ }^{47}$ Nichols believed Nevill began to consider this as early as April but Langley thought Nevill 'only at the last minute hit on the notion of using them (the footballs) as a distraction from the German 
machine guns'. Irwin states Nevill asked permission to use the balls a 'few days' before the attack and the comments in the Billon Valley Baloonist Windy Words trench journal evidence he was even thinking about inscriptions on the balls three days before the attack. $^{48}$

Woodville's accompanying text states that four footballs were used, the same number recorded in the Battalion War Diary, one for each of Nevill's platoons, and this is the number normally cited in references to the football charge. ${ }^{49}$ However, Nevill's brother; the Rev. T.S. Nevill, was certain only two were taken to France and, according to Langley, Nevill and Private Fursey kicked off the two balls. Langley continued 'between casualties the men dribbled, miskicked, laughed and swore their way across the shell-pocked ground, now suddenly without the artillery barrage which had pounded the Germans for the previous week'. ${ }^{50}$ Captain Thorne, who replaced Nevill as 'B' Company commander, had to write condolence letters to the families of the other ranks killed. In a letter to Private Pollard's mother, he notes two balls being used:

You may have seen a lot in the newspapers about the East Surrey's charge with the footballs. That was the charge. Captain Nevill (who was killed) himself kicked off one of the two footballs which the company dribbled across, and you will be proud to hear it was actually your son who kicked off the other one on that historic day the memory of which will live for ever in the records of the regiment, and indeed of the British Nation. ${ }^{51}$

As Nevill knew that only two of his platoons would be in the first wave of the attack, it is likely that he supplied one ball to each of these platoons for the assault's kick-off, two balls were enough.

As to Nevill's fate, Ernest Hetherington recalled: 
After being wounded, I remember lying out in a shell-hole in no-man'sland for some time and then stumbling back to our front line trench. Nevill was lying there dead, having presumably been shot as he climbed over the parapet at zero hour - I doubt whether he ever got a kick at one of those footballs. Our battalion MO, Gimson, was in the trench attending to the wounded he asked me to take Nevill's ring back to his family in England. I $\operatorname{did}^{52}$

Joe Ackerley, an officer in 'C' Company in the attack agrees with Hetherington:

Neville ... who had a football for his men to dribble over to the 'flattened and deserted' German lines and was then going to finish off any 'gibbering imbecile' he might meet with the shock of his famous grin (he had loose dentures and could make a skull like grimace when he smiled) was also instantly killed. ${ }^{53}$

However, Langley notes that Nevill 'fell at the first stretch of German wire, so that there would be no promised prize to the platoon which scored the first "goal" in the enemy's trench'. ${ }^{54}$ Nevill's family received a large number of condolence letters from fellow officers, N.C.O.'s and ordinary soldiers. In a letter to Nevill's sister, Charles Alcock, the only surviving officer of ' $\mathrm{B}$ ' Company, wrote:

Five minutes before zero time he strolled up in his usual calm way, and we shared a last joke before going over. The company went over the top very well, with Soames and your brother kicking off with the company footballs. We had to face a very heavy rifle and machine-gun fire, and nearing the front German trench, the lines slackened pace slightly. Seeing this Wilfred dashed in front with a bomb in his hand, and was immediately 
shot through the head, almost side by side with Soames and Sergeant Major Wells. ${ }^{55}$

Private Sorrell in a letter to Nevill's mother supported this view; he claimed that after being wounded he crawled back to the lines passing Nevill at the German wire and he had been 'shot in the head'. Irwin in a condolence letter to Nevill's family also placed Nevill at the German wire:

He was in command of one of our leading companies ... and led his company most gallantly and with utmost coolness up to the German front line, where he was shot. Death must have been absolutely instantaneous ... He started his company in the assault by kicking off a football which his men dribbled right up to the German trench. ${ }^{56}$

Chaplain Leonard Jeeves attending to the wounded and dying in the front line trench placed Nevill's body 'a few hundred yards away ... my good and brave friend, Captain Nevill, led his men into the fight with footballs. And thus he died. With the Englishman's way of fighting, he went on his way. ${ }^{, 57}$ Therefore, the surviving members of the East Surreys place Nevill's body in two places, Ackerley and Hetherington in the British front line and Alcock, Jeeves, Sorrell and Irwin 400 metres away at the German wire. As Alcock, Sorrell and Irwin's descriptions are in condolence letters, the authors may have written to the bereaved to portray a meaningful, purposeful, painless and courageous death. ${ }^{58}$

Similarly these descriptions differ on who actually kicked off the attack. Alcock (1916) identified Nevill and Soames as the kickers; as Soames was Nevill's second-incommand it is likely that he was leading one platoon and Nevill the other. If one or both of these officers were killed before the balls were kicked then possibly Private Pollard and/or Private Fursey could have kicked the balls and forward. 


\section{Conclusion}

The assault on Montauban was the most successful British attack of the first day of the Somme. ${ }^{59}$ The football 'charge' was used by the press as a good news item, a redeeming feature of a disastrous day, although the footballs were only used in the first 400 metres to the German front wire rather than over a mile and a quarter as claimed by the press. The charge was purported to show that the sporting spirit of the British could not be defeated; it was a triumph of British character over adversity, displaying masculine spirit, unit pride, and élan. It demonstrated that the new volunteer Kitchener formations, representing a united nation, were courageous and victorious in battle. The large scale casualties meant that nearly every home was touched by tragedy and the sacrifices had to be shown to be not in vain to maintain the war effort on the Home and Western Fronts. $^{60}$

Nichols noted that despite the 8/East Surreys suffering heavy losses Nevill's 'quaint whimsical idea had proved to be of real value: the men went on.' Major Irwin, who won a D.S.O. on 1 July, reflected 'I think myself that it did help them enormously, took their minds off it, but they suffered terribly'. ${ }^{61}$ Nevill had recognised that the circumstances would test his men to their limits and his use of footballs was a shrewd psychological move; 'his intention was almost certainly to encourage his men forward' ${ }^{62}$ Billie Nevill would have been one of the first targets for the machine gunners in the Carnoy craters as he led his men out of their trenches three minutes before the rest of the 8/East Surreys; he probably died literally preparing to kick-off one of the two footballs just two weeks before his twenty-second birthday.

British troops advancing into battle kicking a football ahead of them has become part of Britain's collective memory of the First World War. However, research suggests that this happened only twice, the first by the London Irish at Loos and the last occasion 
being by the 8/East Surreys on the first day of the Somme. Both of these units achieved some of the few successes on the first day of these two battles but the use of football was not a cause of success but a coincidence.

It is doubtful if football charges occurred after The Somme because British infantry tactics changed considerably in the light of lessons learned. The British suffered 57,470 casualties out of 120,000 men who went over the top on 1 July. After The Somme soldiers would no longer be asked to walk in lines towards the enemy; platoons became the primary combat unit with specialized sections, all with set objectives and acting in co-ordination with the other sections and platoons as well as with other arms such as tanks. ${ }^{63}$ The football charges are but a footnote to military historians despite becoming a national 'micro-level' myth although charging whilst dribbling or passing a football never became a tradition.

\footnotetext{
${ }^{1}$ Hands, 'Preface', 431; Vamplew, 'Exploding the Myths'.

${ }^{2}$ Adams, 'A Game for Christmas'; Adams, 'Did "Old Bill”' Watch Football'; Adams and

Petney, 'Germany 3- Scotland 2'; Brown and Seaton, Christmas Truce.

${ }^{3}$ Adams, 'Over the Top: "A Foul; a Blurry Foul!"”; Adams, 'Over the Top: Images of the Football Charges'; Holmes, Tommy, xxiii.

${ }^{4}$ Masefield, The Old Front Line, 31.

${ }^{5}$ Hart, The Somme, 20, 57.

${ }^{6}$ Ibid.; Robertson, From Private to Field Marshall.

${ }^{7}$ Langley, The East Surrey Regiment, 72.

${ }^{8}$ Brown, The Somme; Gilbert, Somme; Hart, The Somme; Macdonald, Somme; Middlebrook, The First Day on the Somme; Philpott, Bloody Victory; Roberts, Elegy; Sheffield, The Somme; Sheldon, The German Army on the Somme; van Emden, The Somme.

${ }^{9}$ Nichols, The $18^{\text {th }}$ Division, 2-3; Pearse and Sloman, History of the East Surrey Regiment.

${ }^{10}$ Irwin, 8/East Surrey Regiment.

${ }^{11}$ A. Diaper, 'Kicking Football to the Front: An investigation into the role of English football during the Great War' (MA thesis, University of Central Lancashire, 1997); Evening Standard, November 16, 1914.

${ }^{12}$ Baynes, Far From a Donkey; Adams, 'Football: A counterpoint'; Mason and Riedi, Sport and the Military.

${ }^{13}$ Waquet, 'Sport in the Trenches', 13.

${ }^{14}$ Terraine, General Jack's Diary, 57.

${ }^{15}$ Adams, 'Football: A counterpoint'; Terraine, General Jack's Diary, 91 fn.

${ }^{16}$ War Diary.

${ }^{17}$ Nevill, 'Letter home' No. 50.

${ }^{18}$ Ibid., No. 56.

${ }^{19}$ War Diary.
} 
${ }^{20}$ Maxse, 'Agenda'.

${ }^{21}$ Gliddon, Somme 1916; Pearse and Sloman, History of the East Surrey Regiment.

${ }^{22}$ War Diary; Irwin, 8/East Surrey Regiment.

${ }^{23}$ Harris, Billie.

${ }^{24}$ War Diary; Nevill, 'Letter home' No. 171.

${ }^{25}$ Nichols, The $18^{\text {th }}$ Division.

${ }^{26}$ Heath, 'Document 2554', 1916.

${ }^{27}$ Langley, The East Surrey Regiment, $73 \mathrm{fn}$.

${ }^{28}$ Irwin, 8/East Surrey Regiment.

${ }^{29}$ War Diary, 'Appendix 10, Trench Topics'.

${ }^{30}$ Langley, The East Surrey Regiment, 73.

${ }^{31}$ War Diary, 'Appendix I, Operation Order'.

${ }^{32}$ Ibid.

${ }^{33}$ War Diary. The War Diary would have been written up after the battle and, due to the casualties, probably by an officer not actually involved in the attack.

${ }^{34}$ Middlebrook, The First Day on the Somme, 124.

${ }^{35}$ War Diary, 'Appendix II, Report on the Attack on the Montauban Ridge'; Philpott, Bloody Victory.

${ }^{36}$ Pearse and Sloman, History of the East Surrey Regiment, 224; War Diary.

${ }^{37}$ Nichols, The $18^{\text {th }}$ Division; War Diary.

${ }^{38}$ War Diary. He is buried in Carnoy Military Cemetery (Cem. Ref. E.28); his headstone features the badge of the East Yorkshire Regiment and has had at least one football left by visitors on the author's research visits.

${ }^{39}$ Middlebrook, The First Day on the Somme.

${ }^{40}$ War Diary.

${ }^{41}$ Fussell, The Great War and Modern Memory, 26; Adams, 'Over the Top: Images of the Football Charges'.

${ }^{42}$ Sillars, Art and Survival, 64.

${ }^{43}$ Adams, 'Over the Top: Images of the Football Charges', 205.

${ }^{44}$ A partial list of events is recorded in the 'East Surrey Regiment Scrapbook of Press Cuttings Volume 2.' Surrey History Centre Reference ESR/1/12/12.

${ }^{45}$ Veitch, 'Play up! Play up! 375; G.D. Sheffield, 'Officer-Man Relations, Morale and

Discipline in the British Army, 1902-1922' (PhD diss., King's College, London, 1994), 128;

Harris, Billie, 210.

${ }^{46}$ J.D. Campbell, 'The Army Isn't All Work: Physical Culture in the Evolution of The British Army, 1860-1920' (PhD thesis, The University of Maine, 2003); Eksteins, Rites of Spring;

Moorhouse, Forged by Fire; Parker, Into Battle; Veitch, 'Play up! Play up!

${ }^{47}$ Nichols, The $18^{\text {th }}$ Division. 40.

${ }^{48}$ Langley, The East Surrey Regiment, 73; Irwin, 8/East Surrey Regiment.

${ }^{49}$ Gliddon, The Battle of the Somme; Holt and Holt, Major \& Mrs Holt's Battlefield Guide to the Somme; Middlebrook, The First Day on the Somme; Youel and Edgell, The Somme.

${ }^{50}$ Langley, The East Surrey Regiment, 73.

${ }^{51}$ Thorne, C. Condolence letter to mother of Private George Pollard, 3 September 1916. Surrey History Centre, Guildford. Reference ESR/25/RICH/1. Pollard was 'missing'; he is commemorated on the Thiepval memorial, Pier and Face 6B.

${ }^{52}$ Hetherington, Ernest Cooper. 'Private Papers'. Surrey History Centre Reference ESR/18/3/12.

53 Ackerley, My Father and Myself, 57.

${ }^{54}$ Langley, The East Surrey Regiment, 73.

${ }^{55}$ Alcock, C.W. 'Letter to Miss Nevill', July 15, 1916. Private Papers of Captain C.W. Alcock MBE, Department of Documents.20586, Imperial War Museum.

${ }^{56}$ Sorrell, J. 'Letter to Mrs Nevill' and Irwin, Alfred Percy Bulteen. 'Manuscript letter' 15 July, 1916., Private Papers of Captain W. P. Nevill, Department of Documents.11213, Imperial War 
Museum. According to Regimental records, Sorrell accompanied the ball on several cash raising visits to garden parties later in the war.

${ }^{57}$ Jeeves, 'In the Battle of the Somme', 27.

${ }^{58}$ Winter, Sites of Memory; Fussell, The Great War and Modern Memory.

${ }^{59}$ Gilbert, Somme.

${ }^{60}$ Sillars, Art and Survival.

${ }^{61}$ Nichols, The $18^{\text {th }}$ Division, 41; Irwin, 8/East Surrey Regiment.

${ }^{62}$ Hart, The Somme, 104.

${ }^{63}$ General Staff, 1917a. SS.143 Instructions for the Training of Platoons for Offensive Action. Base Stationary Unit, France: Army Printing and Publishing Services; Moorhouse, Forged by Fire.

\section{References}

Ackerley, J.R. My Father and Myself. London: The Bodley Head, 1968.

Adams, Iain. 'Over the Top: “A Foul; a Blurry Foul!"' The International Journal of the History of Sport 26, no. 6 (2012): 813-831.

Adams, Iain. 'A Game for Christmas? The Argylls, Saxons and Football on the Western Front, December 1914'. The International Journal of the History of Sport 32, no. 11-12 (2015): 13951415.

Adams, Iain. 'Did "Old Bill" Watch Football? Bruce Bairnsfather and the Christmas Truce'. In Sport and Leisure on the Eve of the First World War, ed. Dave Day, 22-46. Crewe: MMU Sport and Leisure History, 2016.

Adams, Iain. 'Over the Top: Images of the Football Charges of the Great War'. Journal of Sport History 43, no. 2 (2016): 192-211.

Adams, Iain. 'Football: A counterpoint to the procession of pain on the Western Front, 1914-18?' Soccer \& Society 16, no. 2-3 (2015): 217-231.

Adams, Iain and Trevor Petney. 'Germany 3 - Scotland 2, No Man's Land, $25^{\text {th }}$ December, 1914; Fact or Fiction?' In The Bountiful Game? Football Identities and Finances, ed. Jonathan Magee, Alan Bairner and Alan Tomlinson, 21-41. Oxford: Meyer and Mayer Sport (UK), 2005.

Baynes, John. Far From a Donkey: The Life of General Sir Ivor Maxse. London: Brassey's, 1995.

Brown, Malcolm and Shirley Seaton. Christmas Truce. London: Leo Cooper, 1984.

Brown, Malcolm. The Somme. London: Pan, 2002.

Eksteins, Modris. Rites of Spring: The Great War and the Birth of the Modern Age. London: Papermac, 2000.

Falls, Cyril. 1930. War Books: A Critical Guide. London: Peter Davies, 1930 
Fussell, Paul. The Great War and Modern Memory. New York: Oxford University Press, 1975.

Gilbert, Martin. Somme: The Heroism and Horror of War. London: John Murray, 2006.

Gliddon, Gerald. The Battle of the Somme: A Topographical History. Stroud: Sutton, 1996.

Gliddon, Gerald. Somme 1916: A Battlefield Companion. Stroud: The History Press, 2009.

Hands, Robert. 'Preface: They Also Served - Re-evaluating and Reconsidering the Neglected'. The International Journal of the History of Sport 28, no. 3-4 (2011): 429434.

Harris, R.E. Billie: The Nevill Letters: 1914-1916. Uckfield: The Naval and Military Press, 2003.

Hart, Peter. The Somme. London: Weidenfeld \& Nicolson, 2005.

Heath, P.G. Private Papers of P.G. Heath MC, Department of Documents.11043. Imperial War Museum.

Holmes, Richard. Tommy: The British Soldier on the Western Front 1914-1918. London: HarperCollins, 2004.

Holt, Tonie and Valmai Holt.,V., Major \& Mrs Holt's Battlefield Guide to the Somme. Barnsley: Leo Cooper, 2003.

Irwin, Alfred Percy Bulteen. 8/East Surrey Regiment, $55^{\text {th }}$ Brigade, $18^{\text {th }}$ Division. Department of Sound Records: A Irwin, AC211, 1973. http://www.iwm.org.uk/collections/item/object/80000210 (accessed May 12, 2017).

Jeeves, L.L. 'In the Battle of the Somme' . Typescript article, 1916. Private Papers of Reverend LL Jeeves CF. Department of Documents.4768, Imperial War Museum Documents.

Langley, Michael. The East Surrey Regiment. London: Leo Cooper, 1972.

Macdonald, Lyn. Somme. London: Penguin, 1993.

Masefield, John. The Old Front Line, London: William Heinemann, 1917.

Mason, Tony and Eliza Riedi. Sport and the Military: The British armed forces 18801960. Cambridge: Cambridge University Press, 2010. 
Maxse, Ivor. Agenda, Divisional Commander's Conference, April 26, 1916. Maxse, Ivor. Private Papers, File 17/2/2. Department of Documents.3255, Imperial War Museum.

Middlebrook, Martin. The First Day on the Somme: 1 July 1916. London: Penguin, 2001.

Moorhouse, Brendon. Forged by Fire: The Battle Tactics and Soldiers of a WWI Battalion, The $7^{\text {th }}$ Somerset Light Infantry. Staplehurst: Spellmount, 2003.

Nevill, Wilfred Percy. Letter home from France. Private Papers of Captain W. P. Nevill, Department of Documents.11213, Imperial War Museum.

Nichols, George Herbert Fosdike. The $18^{\text {th }}$ Division in the Great War. Edinburgh:

William Blackwood and Sons, 1922.

Parker, Ernest. Into Battle 1914-18. London: Longmans, 1964.

Pearse, Hugh.W. and Sloman, H.S. History of the East Surrey Regiment 1914-1917. London: The Medici Society, 1923.

Philpott, William. Bloody Victory: The Sacrifice on the Somme and the Making of the Twentieth Century. London: Little Brown, 2009.

Roberts, Andrew. Elegy: The First Day of the Somme. London: Head of Zeus, 2015.

Robertson, William Robert. From Private to Field Marshall. London: Constable, 1921.

Sheffield, Gary. The Somme. London: Cassell, 2004.

Sheffield, Gary and John Bourne, eds. Douglas Haig: War Diaries and Letters 19141918. London: Wiedenfield and Nicolson, 2005.

Sheldon, Jack. The German Army on the Somme 1914-1916. Barnsley: Pen \& Sword, 2005.

Sillars, Stuart. Art and Survival in First World War Britain. New York: St. Martin's Press, 1987.

Terraine, John, ed., General Jack's Diary: War on the Western Front 1914-1918. London: Cassell, 2000.

Vamplew, Wray. 'Exploding the Myths of Sport and the Great War: A First Salvo'. The International Journal of the History of Sport 31, no. 18 (2014): 2297-2312.

Van Emden, Richard. The Somme. Barnsley: Pen \& Sword, 2016. 
Veitch, Colin. "Play up! Play up! And Win the War!" Football, the Nation and the First World War 1914-1915'. Journal of Contemporary History, 20 no.3 (1985), 363-378.

War Diary, '8 Battalion East Surrey Regiment'. WO 95/2050/1, The National Archives Kew, Surrey.

Waquet, Arnaud. 'Sport in the Trenches: The New Deal for Masculinity in France'. In Sport, Militarism and the Great War: Martial Manliness and Armageddon, ed. Thierry Terret and J.A. Mangan, 10-29. Abingdon: Routledge, 2012.

Winter, Jay. Sites of Memory, Sites of Mourning: The Great War in European Cultural History. Cambridge: Cambridge University Press, 1995.

Youel, Duncan and David Edgell. The Somme: Ninety Years On - A Visual History. London: Dorling Kindersley, 2006. 